\title{
Labienus and Sceva: Two Classical Supporting Characters and Their Early Modern Dramatic Life in Fletcher and Massinger's The False One
}

This note explores the early modern dramatic reception of two characters, Titus Labienus and Cassius Scaeva, featuring in Julius Caesar's Commentaries and subsequently reincarnated in Fletcher and Massinger's The False One (ca 1620). I investigate the ostensible reversal in the depiction of status and dramaturgical importance of the two characters in the play as compared to the Commentaries. Since Lucan's Civil War, accepted as a major source of the play, marginalizes Labienus and elevates Scaeva's exploits, this note considers the extent to which Lucan's epic poem conditions the dramatic portrayal of Labienus and Scaeva.

The civil war between Caesar and Pompey (49-45 вс), heralding the transitional period between republic and empire, was a popular subject in Elizabethan and Jacobean drama. Participating in the civil war but merely existing in the shadow of the great protagonists are numerous minor personalities; emerging from a murky historical past, with their less clearly defined identities already subjected to fragmentation by antiquity, they are nevertheless successfully reincarnated in early modern Roman plays. ${ }^{1}$ This paper focuses on two such personalities in Fletcher and Massinger's The False One: the Caesarean centurion Scaeva, and Titus Labienus, the ex-Caesarean legate and a supporter of Pompey in the civil war.

Although The False One (ca 1620) was published in the 1647 Beaumont and Fletcher first folio, its authors were Massinger (acts 1 and 5) and Fletcher (acts 2, 3, and 4). The play tells the story of Caesar's exploits in Egypt, his meeting and falling in love with Cleopatra, and his victory in the Alexandrian war. As a subplot, the play features the exploits of Septimius, a Roman soldier and Pompey's murderer, subsequently oscillating between goodness and wickedness. ${ }^{2}$

Miryana Dimitrova (miryana.dimitrova@gmail.com) is an independent scholar. She obtained her PhD from the Classics department at King's College, University of London. 
Labienus and Scaeva, characters originally depicted in Julius Caesar's Commentaries, experience a peculiar reversal of their dramaturgical importance in The False One. Labienus, a prominent figure in Caesar's writings, appears only to deliver an account of Pompey's defeat at Pharsalus to the court of Ptolomy. On the other hand, Scaeva, mentioned only once by Caesar, emerges in The False One as one of Caesar's captains and a 'free thinker' who accompanies the general and acts as a foil to his infatuation with Cleopatra. I suggest that this particular alteration of dramaturgical importance grows out of the influence of Lucan's epic Civil War, which also allows a brief appearance of Labienus, whilst granting an aristeia (or indeed, a subversion of traditional epic aristeia) to Scaeva.

The use of Lucan as a literary source in early modern drama is inextricably connected to the importance of the epic for the contemporary political debates and its powerful visual depiction of the civil war and its instigator, Julius Caesar. In effect, the consideration of Fletcher and Massinger's decision to include Labienus and Scaeva may contribute to a better understanding of the dramatists' attitude towards Caesar and the extent to which they appropriated Lucan as a source. After briefly noting the original depiction of the characters in Caesar's Commentaries, I discuss their portrayal in the play in the light of Lucan's influence.

\section{Titus Atius Labienus and Cassius Scaeva}

Labienus was a historical personality and an active agent in the political life of late republican Rome. He served as a legatus pro praetore with Caesar in Gaul and was appointed governor of Cisalpine Gaul in 51 вс. ${ }^{3}$ Certainly, Caesar's works have had a decisive influence on the shaping of Labienus's image for posterity. Labienus's contribution to the conquest of the Gallic tribes is undeniable and Caesar in his Gallic War commends his achievements by creating an overall impression of a productive collaboration and perfect coordination between general and legate. ${ }^{4}$ Nevertheless, Labienus, who was effectively Caesar's second-in-command, changed his allegiance and took Pompey's side on the brink of the civil war. Caesar might have not envisaged this act and so, ironically, the positive image he had given his legate served his Civil War characterization purposes brilliantly: the contrast between Labienus's positive depiction in the Gallic War and his presence on the enemy side in the Civil War tacitly but uncompromisingly reminds the reader of the legate's treachery. ${ }^{5}$ Labienus escaped after the battle at Pharsalus 
and joined the Pompeian forces in Africa. After Caesar's victory at Thapsus in 46 BC, he moved to a new theatre of war in Spain and fought for Pompey's sons. He died during the battle of Munda, which marked Caesar's decisive victory in early $45 \mathrm{BC}$.

When the action of the civil war moved to Greece in 48 вс, Caesar constructed a blockade around the camp of Pompey at Dyrrachium and the latter reacted by constructing a corresponding inner line of defence. The two sides engaged in numerous skirmishes, of which the most remarkable features the heroic exploits of the Caesarean centurion Scaeva. Caesar reports that Scaeva's valiant service saved the fort; the grateful general rewarded his faithful soldier with 200,000 sesterces and promoted him from eighth rank to first centurionate (Civil War 3.53). Caesar treats the battle action only briefly, and yet, in a cunningly straightforward way. By stating the great damage on Scaeva's shield, pierced by 120 arrows, and by noting that the soldiers have collected 30,000 darts in the area, he evokes the ferocity of the attack on the fortification.

\section{Labienus and Sceva in The False One - via Lucan}

Although, like other works in the period, The False One fuses different sources and influences, Caesar's Commentaries despite their popularity remain of little importance for Fletcher and Massinger's work. On the other hand, Lucan's poem Civil War is generally considered to have made a distinctive mark on the play. Paulina Kewes observes that it includes 'several set pieces translated verbatim from Lucan's Books VII and VIII that would have been instantly recognizable to anyone with grammar school education'. ${ }^{6}$ Since Labienus and Scaeva both feature in Lucan's Civil War, we can reasonably accept that they have become familiar to the dramatists via the epic. The inclusion of these minor characters, moreover, points to Fletcher and Massinger's wide-ranging interest in using Lucan as a source, not limited to themes and characterization of the protagonist. Such scope of influence is logical, given the fact that the epic was a highly valued text in the seventeenth century, its impact ranging from implications on political discourse to stylistic influences on drama. Stating that the influence of Lucan is underestimated, J.A.K. Thomson claims that 'much of Elizabethan poetry that is credited to Seneca should be credited to Lucan'; ' William Blissett also aserts the interconnection of Seneca and Lucan in terms of their poetic influence: 'though Seneca wrote drama and Lucan epic, both are writers of "tragedy" 
in the mediaeval sense'. 8 The poem's importance for the characterization of Caesar and other bellicose leaders in English drama is immense as Elizabethan and Jacobean villains from Marlowe's Tamburlaine to Jonson's Sejanus are steeped in Lucanian intense furor and hubris.

The False One implicitly but consciously measures itself against other works about the civil war and Caesar - the prologue states that the play presents a story that differs from other existing works focusing either on Caesar's assassination or Antony's relationship with Cleopatra. Any appearance of Julius Caesar on the early modern English stage reflects the complexity of the reception of the cultural myth of the Roman general in the light of the contemporary socio-political context; in this respect, The False One is no exception. As a major factor for the cultural reception of Caesar, Lucan's poem sublimates the archetypal opposition to tyranny on a grand epic scale. Its inherent republicanism is clouded by the nihilism of its author who, although opposing Caesar's ambition, does not vindicate Pompey completely. This stance not only allowed the poem to be interpreted in the light of republicanism, but also rendered its characteristic ambiguity, especially regarding the assessment of Caesar's hubris in the light of contemporary political debates. Recent contributions to the study of early modern drama by David Norbrook, Andrew Hadfield, and Patrick Cheney, as well as Edward Paleit's work on the reception of Lucan, have revisited the assumptions of Lucan's republicanism and have demonstrated the dialectical nature of the epic's influence in relation to specific works and the cultural milieu of the period. ${ }^{9}$

Regarding the specific implications of The False One, Freyja Cox Jensen argues that Fletcher and Massinger joined the ranks of those who 'appropriated Lucan for anti-court purposes, reflecting contemporary concerns for James' perceived closeness with Spain, and the crisis of the Palatinate.' ${ }^{10}$ Accordingly, seen through the prism of the play's contemporary context, the assessment of Caesar in The False One has been subjected to contrasting views. Paulina Kewes states that the play presents Caesar as 'tyrant in the making'; encouraging a more multi-layered perspective of the character, John Curran, Jr, rightly observes that 'Unless we privilege one slant, which the play refuses to do, we glean from the various accounts of Caesar a picture of a man ... in either respect having shades of both a tyrant and a virtuous, successful leader.' ${ }^{11}$ Since, as supporting characters, Labienus and Sceva inevitably gravitate around Caesar, I suggest that their function is to foster the 
ambiguity, already established by Lucan, which has shaped Caesar's image both as a political allegory and as a personality.

Compared to the infamy inflicted on Labienus in the Commentaries, the portrayal of Caesar's former right hand in The False One is distinctly more timid; he appears once and performs the role of the messenger. Labienus and King Ptolomy enter while the leading Egyptians - Achillas, Achoreus, and Photinus - muse over the events of the war (1.1). Achillas recognizes the nuntio as 'Caesars Lieutenant in the Wars of Gaul' (1.1.196) who has taken Pompey's side. ${ }^{12}$ Labienus narrates the account of the battle at Pharsalus, highlighting the tragic aspects of the unlawful civil conflict. $\mathrm{He}$ also informs Ptolomy and his advisors that Pompey is heading towards the Egyptian shores, expecting help from the king, whose father Pompey has supported before. Replying that the message will be considered, Ptolomy dismisses Labienus and the nuntio disappears from the play.

Fletcher and Massinger's treatment of Labienus is noticeably similar to that by Lucan, who also grants him a cameo appearance. In the Civil War, we hear about Labienus's treachery from Caesar, who does not miss the opportunity to highlight his legate's betrayal: when facing the mutiny of his soldiers, which he eventually quells with powerful rhetoric and the ability to instigate fear, Caesar remarks: 'fortis in armis / Caesareis Labienus erat: nunc transfuga uilis / cum duce praelato terras atque aequora lustrat' [Labienus was eminent in war while he bore my arms; now, a despised deserter, he hurries over land and sea with the leader whom he preferred to me] (Civil War 5.345-7). ${ }^{13}$ Next we see Labienus accompanying Cato in Libya in the latter's march through the desert. At the temple of Jupiter Ammon, Labienus encourages Cato to consult the oracle about the outcome of the war and the future of Rome (9.557-9); however, relying on his Stoic belief in fate, Cato refuses to seek advice. These two appearances complete Labienus's portrayal by Lucan.

Both The False One and Lucan's poem obliterate Caesar's heavy authorial bias of the Commentaries, thus inevitably affecting the image of the legate. By casting him as a messenger, Fletcher and Massinger allow Labienus an independent voice to 'revenge' himself in offering his version of the battle, a voice which Lucan's Labienus does not possess. The single appearance of Labienus in The False One, although an apparent dramatic debasement, is nevertheless important. By painting a vivid picture of the civil war, he sets the background of the action of the play. Even though he only appears once, Labienus is respected by the Egyptians - when Achillas introduces him, 
he notes that Labienus has chosen the better cause. Accordingly, Labienus presents Pompey as giving the sign of retreat in order to prevent further loss of lives, thus setting him in contrast to the ambitious and ruthless Caesar.

Paulina Kewes has pointed out that Labienus' speech, modelled on Lucan's Books VII and VIII, supports the anti-Caesarean agenda of the play. ${ }^{14}$ However, the dramatists' bold use of the source material does not imply a completely negative judgment of the protagonist. Labenius's portrait of Caesar is contestable when contrasted with the general's conduct, which shows distinctive traits of nobleness - a good example is the soliloquy in which Caesar self-consciously regrets the bloodshed of war he caused (2.3). Edward Paleit has argued convincingly that Caesar's benevolence is set in contrast to the wickedness of Photinus, who is presented as the unruly courtier, plotting to usurp royal power. ${ }^{15}$ Although not necessarily partisans of the tyrant-to-be Caesar, Fletcher and Massinger nevertheless draw a picture of an ambitious, bold, and virtuous general, thus ruling out any unequivocal acceptance of his role as the villain. This pattern followed in other dramatic representations of the civil war drawing on Lucan, most notably George Chapman's Caesar and Pompey (ca 1605), which Blissett has described as the 'most Lucanic conception of Caesar on the Elizabethan stage. ${ }^{16}$ Caesar's ambivalent character is rooted in Lucan's love-hate attitude - the general is elevated to demonic hubristic heights only to be condemned by the poet. Pompey, whose fate is inevitably intertwined with his rival's, also suffers from Lucan's fierce grudging admiration for Caesar - despite Pompey's famous apotheosis, he is not made the paragon of virtue and fortitude. As reflected in the early modern reception of Pompey, audiences and readers see him as a tragic and possibly virtuous figure but not necessarily the 'healthier' alternative to Caesar. ${ }^{17}$

Liberated from Caesar's authorial damnation, Labienus does emerge as a more independent figure; yet, Fletcher and Massinger's decision to grant a fictional voyage to Egypt to a prominent Pompeian and ex-Caesarean in fact adds dramaturgical weight to the news of Caesar's victory. Labienus's function is to offer an alternative to the dominant Caesarean perspective and to advocate the 'better cause'; however, the fact that the legate is not granted a more important role is a tacit reminder to the audience that he remains on the losing side.

Despite their seeming endorsement, Fletcher and Massinger do not accept the Caesarean side unconditionally. Caesar's self-conscious ruminations about his role as a perpetrator in the war do not necessarily exonerate him, and as the play progresses the figure of Scaeva appears as a dark shadow from 
the Lucanian past which threatens to eradicate any romantic or remorseful tendencies Caesar might be prone to. In contrast to Labienus, Scaeva evolves from an episodic appearance in the Commentaries to Caesar's closest associate in The False One. Spelled as 'Sceva' and characterized by the authors as 'a free speaker', he appears frequently throughout the play and enjoys an even higher status than Caesar's other captains Antony and Dolabella.

Notwithstanding the unwavering fidelity to his general, Sceva possesses a distinctive independent personality and constantly subjects Caesar's actions to scrutiny and criticism. His remark during the scene in which Caesar is presented with Pompey's head is a case in point - although he shares Caesar's contempt for the Egyptians, when witnessing the general's lament for his enemy, Sceva wonders what history can only speculate about: 'How he would look if Pompey were alive again, / But how he would set his face?' (2.1.164-5). Seeing the episode as a demonstration of Caesar's hypocrisy, Ira Clark draws an insightful parallel between Caesar's reaction and Queen Elizabeth's (equally superficial) act of mourning and temporary banishment of her privy council for ordering the execution of Mary, queen of Scots. John Curran, Jr, however, argues against this relatively commonplace line of interpretation: 'while the playwrights consult Lucan and allow for the long tradition of Caesar's fakery in this moment, they stress the alternative tradition that not only has him crying real tears, but also encapsulating with them his magnanimity's most admirable aspect, clemency'; Edward Paleit describes Caesar's tribute to Pompey as 'magnanimous in the Shakespearean tradition of Romanitas' [author's italics]. ${ }^{18}$ These more dynamic interpretations are an apt response to the effective dramaturgical strategy to challenge the veracity of reported events by contrasting them with the stage reality; the contrast exemplified by Labienus's account of the battle and Caesar's penitent selfassessment is sustained in Sceva's refusal to take Caesar's apparently sincere eulogy for Pompey at face value.

Sceva's criticism is particularly sharp where Caesar's relationship with Cleopatra is concerned. Ironically, he is the one to bring the 'packet' concealing the Egyptian queen (2.3). He is unaware of its contents but shrewdly suspects that there 'may be a Rogue within, to do a mischief' (2.3.74) and, with the bravery and loyalty characteristic of the Scaeva familiar from the Commentaries, he says, 'I pray you stand farther off, if there be villany, / Better my danger first' (75-6). When Cleopatra emerges, Caesar is immediately fascinated by the young queen, whereas Sceva demonstrates his suspicion and dislike from the moment he sees this 'tempting Devill' (82). 
Sceva remains alert to Cleopatra's possibly perilous influence on the general and scorns his infatuation throughout the play. On one occasion Sceva recounts his own heroic endurance (a possible inter-textual reference to his stand at Dyrrachium) to express his disappointment by the general's weakness:

SCEVA Am I he

That have receiv'd so many wounds for Cesar?

Have I endur'd all hungers, colds, distresses,

To ban the blood I lost for such a Generall? (2.3.118-24)

To this strong and emotional accusation, Caesar responds with 'offend no more; be gon' (125), a line indicating that, although a free speaker, Sceva remains his subordinate. As the action of the play progresses, however, we notice that Sceva's ability to check Caesar's unhealthy affection is in fact decisive for the latter's success. ${ }^{19}$ When Caesar's captains bring the news of the Egyptian attack, the general, as if awakened from a slumber, promptly prepares for battle; realizing that he has let his guard down, he timidly accepts Sceva's sarcasm that perhaps the god of love should fight for him (4.2.173). The Caesareans escape from the Egyptian blockade and upon their victorious return after the battle, Caesar meets Cleopatra; yet Sceva interferes reminding him that Photinus and Achillas have escaped, and prevents any emotional digression: 'By Venus, not a kisse / Till our worke be done' (5.4.185-6). Caesar dutifully obeys the voice of martial reason. When he returns bringing the heads of the traitors, Caesar closes the play by addressing Cleopatra, but also beckoning to Sceva: 'All is but death (good Sceva) / Be therefore satisfied' (201-2).

These examples demonstrate the strong connection between captain and general and present Sceva as a sharp-tongued individual who has come a long way from his episodic role in Caesar's Commentaries. Able to steer the general's emotions and encourage his martial impulses, Sceva emerges as Fletcher and Massinger's confident dramaturgical agent. He brings with him a sense of the Lucanian furor, intrinsic to his depiction in the epic.

Lucan's take on Scaeva reconstructs his exploits at Dyrrachium as an allusion to conventional epic aristeia, or in fact a subversion of the classical model — as John Henderson put it: 'Lucan had there used his entire armoury of hyperbolic and perverse colores to upset the epic topoi of a hero-warrior's 
aristeia. ${ }^{20}$ Scaeva resolves not to leave his position at the breached defences and, as an uncanny evidence of Caesar's spirit protecting him, despite his numerous wounds he survives for an unnaturally long period of time (Civil War 6.142-262). Deploring his fellow soldiers's fear, Scaeva attacks with every weapon available, including corpses which he hurls towards the enemy; then, compared to a leopard, he jumps into the enemy squadron. His ultimate feat is to pretend to surrender in order to be taken to Pompey's camp as a deserter; when a certain Aunus recklessly approaches him, denouncing death, Scaeva cuts him down. Finally, when the centurion is saved by his comrades, Lucan concludes: 'Infelix, quanta dominum uirtute parasti!' [Unhappy wretch, how bravely you fought that a tyrant might rule over you!] (6.262).

Lucan, of course, condemns Scaeva's valour as demonic folly, instigated by Caesar's authority and his infernal charisma. The episode has attracted much scholarly attention and has been considered both as a subversion of epic conventions and in relation to its performative aspects, the latter discussed in Matthew Leigh's landmark study on the poem. Vanessa Gorman considers the centurion as an extension of Caesarean ambition and uncompromising zeal to put an end to the Republic: 'in this aristeia Lucan is not glorifying Caesarean valor, but mocking it with hyperbolic irony'. According to Charles Martindale, Scaeva serves as an illustration of the perversion of courage of the Caesareans: he does not know that true virtus requires a just cause. ${ }^{21}$

Interestingly, in the last lines of the poem, when Caesar faces peril in Alexandria, Scaeva reappears, emerging as an example for Caesar himself to follow: 'dubiusque timeret / optaretne mori respexit in agmine denso / Scaeuam perpetuae meritum iam nomina famae' [as he doubted whether to fear death or pray for it, he saw Scaeva in the serried ranks, that Scaeva who had already won immortal glory] (10. 542-4). In Lucan's poetic reality, Caesar's success is still far from secure. So there they stand, general and centurion, at the end of the poem - Caesar has inspired Scaeva at Dyrrachium, now Scaeva is to assure the leader in his success by acting as a mirror to his martial prowess. Although the epic does not depict close camaraderie between Caesar and Scaeva, the two are united by the spirit of war; they act in unison and offer mutual support in moments of peril.

Lucan's Scaeva has left a mark on the depiction of the centurion in ancient historiography; the accounts of Suetonius, Plutarch, Florus, Appian, and Valerius Maximus enrich the marginal character of the Commentaries with visual details evocative of his ferocity. But the dramatization in The False One creates a fully rounded character deeply influenced by Lucan's portrayal 
of the centurion. The suspicion with which he approaches the contents of the 'packet' concealing Cleopatra indicates Sceva's readiness to defend his general at all costs. Although he is unable to destroy the menace he takes the queen to be, by controlling Caesar's passions and inspiring his bellicose impulses, Sceva successfully fuses his outspoken nature with the respect for his superior. Yet, despite being described as a 'free thinker', Sceva's audacious opposition to Caesar in fact serves to advance the general's authority. His decisive impact on Caesar points to a quasi-Lucanian symbiosis with the leader which reinforces the latter's ambition and ruthlessness. Fletcher and Massinger have seemingly redeemed Scaeva from his monstrous Lucanian image by making him more light-hearted and at times even comical. His fanatical impulses, devotion to his general, and zeal are not eradicated; instead, they are transferred from his willingness to kill fellow citizens to envisaging monstrous punishment for Pompey's murderer and the treacherous Egyptians: 'I'le beat him [Ptolomy] and his Agents (in a morter) / Into one man, and that one man I'le bake then' $(2.1 .170-1) .{ }^{22}$

Since he is clearly infused with Lucanian martial frenzy, Sceva's performance as the voice of reason opposing Caesar's love frenzy appears paradoxical. By way of presenting both Caesar's love for Cleopatra and its supposedly corrective activity — war - as irrational, the dramatists imply the absence of reason in Caesar's world in which ambition and pride is driven by furor. Therefore, despite depicting Caesar in a more positive light than Lucan, Fletcher and Massinger nevertheless invite the audience to consider the character as an oxymoronically self-conscious hubristic hero. For the early modern audience, intellectually conditioned by the Renaissance new wave of stoicism which problematized excessive emotion, pride, and fury, the image of Caesar in The False One remained challenging and ambiguous.

The bottom line of this examination is that, although originally depicted in Julius Caesar's Commentaries, the episodic appearance of Labienus and the aristeia of Scaeva in Lucan have determined the interpretation of these characters in The False One. Their function in the play is to foster dramatic tension related to Caesar: in the case of Labienus, it arises from the contrast between Caesar's self-conscious behaviour and the interpretation of the nuntio's account of the battle at Pharsalus by the losing side; Sceva epitomizes the friction between Caesar's romantic infatuation and his militant nature; by encouraging his ambition based on aggression and greed, Sceva becomes an extension of (Lucanian) Caesarean hubris. The resulting tension contributes to the ambivalent image of Caesar as a protagonist, which echoes the 
multi-layered reception of both Caesar and Lucan in the literature, drama, and political thought in the seventeenth century.

\section{Notes}

1 An excellent list of Roman plays in English is offered by Clifford Ronan, Antike Roman': Power Symbology and the Roman Play in Early Modern England, 15851635 (Athens, GA, 1995), 177-9.

2 On the authorship, sources, and dating of the play see Fredson Bowers, The Dramatic Works in the Beaumont and Fletcher Canon, vol. 8, The False One, ed. Robert Turner (Cambridge, 2008), 115-16. For different readings of the meaning of the play's title, see Sarah Hatchuel, Shakespeare and the Cleopatra/Caesar Intertext: Sequel, Conflation, Remake (Madison, 2011), 111-13.

3 On Labienus's life and career, see Frank Frost Abbot, 'Titus Labienus', The Classical Journal 13 (1917), 4-13; Ronald Syme, 'The Allegiance of Labienus', The Journal of Roman Studies 28 (1938), 113-125, doi: http://dx.doi.org/10.2307/296654; Wm. Blake Tyrrell, Biography of Titus Labienus, Caesar's Lieutenant in Gaul (https://www .msu.edu/-tyrrell/Labienus.pdf, 4-5); Wm. Blake Tyrrell, 'Labienus' Departure from Caesar in January 49 BC', Historia: Zeitschrift für Alte Geschichte 21 (1972), 424-40.

4 Julius Caesar, The Conquest of Gaul, trans. S.A. Handford (London, 1982). On the portrayal of Caesar's legates in the Commentaries see Kathryn Welch, 'Caesar and His Officers in the Gallic War Commentaries', Kathryn Welch and Anton Powell (eds), Julius Caesar as Artful Reporter: The War Commentaries as Political Instruments (London, 1998); Tyrrell claims that there was never sincere friendship between Labienus and Caesar ('Labienus' Departure', 429).

5 Julius Caesar, Civil War, trans. J. Gardner (New York, 1976). For a detailed analysis of Caesar's depiction of Labienus: William Batstone and Cynthia Damon, Caesar's Civil War (Oxford, 2006), 106-9.

6 Paulina Kewes, 'Julius Caesar in Jacobean England', Seventeenth Century 17 (2002), 174.

7 J.A.K. Thomson, Shakespeare and the Classics (London, 1952), 231.

8 William Blissett, 'Lucan's Caesar and the Elizabethan Villain', Studies in Philology 53 (1956), 556-7. A comprehensive account on Lucan's impact on English literature appears in Oswald A.W. Dilke, 'Lucan and English Literature' in D.R. Dudley (ed.), Neronians and Flavians: Silver Latin I (London, 1972). 
9 David Norbrook, Writing the English Republic: Poetry, Rhetoric and Politics, 16271660 (Cambridge, 2000), 23-63; Andrew Hadfield, Shakespeare and Republicanism (Cambridge, 2005), 54-99; Patrick Cheney, Marlowe's Republican Authorship: Lucan, Liberty, and the Sublime (Basingstoke, 2009); Edward Paleit, War, Liberty, and Caesar: Responses to Lucan's Bellum Ciuile, ca. 1580 - 1650 (Oxford, 2013); for the attitude towards Julius Caesar, conditioned by Lucan, see Edward Paleit, 'The Caesarist Reader and Lucan's Bellum Ciuile, ca. 1590 to 1610', The Review of English Studies, New Series 62 (2010), 212-40, doi: http://dx.doi.org/10.1093/res/hgq088.

10 Freyja Cox Jensen, Reading the Roman Republic in Early Modern England (Leiden, 2012), 137; for a discussion of the play's topical allusions and contemporary reception of Lucan, including James I's attitude towards the epic, see Kewes, 'Julius Caesar', 172-9; Ira Clark, The Moral Art of Philip Massinger (Lewisburg and London, 1993), 103-14.

11 Kewes, 'Julius Caesar', 173; John Curran Jr, 'Fletcher, Massinger, and Roman Imperial Character', Comparative Drama 43 (2009), 321, doi: http://dx.doi.org/10.1353/ cdr.0.0072.

12 All quotations from the play are taken from Fredson Bowers, The Dramatic Works in the Beaumont and Fletcher Canon.

13 Lucan, Civil War, trans. J.D. Duff (Loeb Classical Library) (Cambridge MA, 1962). All subsequent quotations are taken from this edition.

14 Kewes, 'Julius Caesar', 175.

15 Paleit, War, Liberty, and Caesar, 140-51.

16 Blissett, 'Lucan's Caesar', 570.

17 Jensen, Reading the Roman Republic, 131-6.

18 Clark, The Moral Art, 111; Curran, 'Fletcher', 322; Paleit, War, Liberty, and Caesar, $148-9$.

19 In George Bernard Shaw's Caesar and Cleopatra, Rufio - also Caesar's close associate - is effectively a reincarnation of Sceva. On the parallels between Caesar and Cleopatra and The False One, see Gordon Couchman, This Our Caesar: A Study of Bernard Shaw's Caesar and Cleopatra (The Hague; Paris, 1973).

20 John Henderson, Fighting for Rome: Poets and Caesars, History and Civil War (Cambridge, 1998), 172; see also Nicola Homke, 'Bit by Bit Towards Death — Lucan's Scaeva and the Aesthetisization of Dying', Nicola Homke, Christiane Reitz (eds), Lucan's Bellum Civile. Between Epic Tradition and Aesthetic Innovation (Berlin, 2010), 91-104.

21 Vanessa Gorman, 'Lucan's Epic "Aristeia" and the Hero of the "Bellum Civile", The Classical Journal, 96.3 (2001), 278; Charles Martindale, 'The Politician Lucan', 
Greece \& Rome 31 (1984), 69, doi: http://dx.doi.org/10.1017/s0017383500027911; Matthew Leigh, Lucan: Spectacle and Engagement (Oxford, 1997), 158-90.

22 Sceva's fanatical criticism of Caesar's affair, seen in the light of Lucanian characterisation: Curran, 'Fletcher', 325. 
